\title{
PENGARUH AKSES KEUANGAN TERHADAP PERTUMBUHAN UKM DENGAN LITERASI KEUANGAN SEBAGAI VARIABEL MODERASI
}

\author{
Made Ayu Desy Geriadi ${ }^{1}$ Luh Erynayati $^{2}$ Ni Putu Yuliana Ria Sawitri ${ }^{3}$
}

Article history:

Submitted: 23 Desember 2020

Revised: 3 Januari 2021

Accepted: 24 Februari 2021

\section{Keywords:}

Access to finance;

Financial literacy;

Growth;

\section{Kata Kunci:}

Akses keuangan;

Literasi keuangan;

Pertumbuhan;

\section{Koresponding:}

Fakultas Ekonomi dan Bisnis

Universitas Ngurah Rai,

Denpasar, Bali, Indonesia

Email: ria.sawitri@unr.ac.id ${ }^{1}$

\section{Abstract}

This study is intended to determine how the role of financial literacy in moderating the relationship between access to finance and growth. The exploration area was carried out in Denpasar. The total number of tests taken was 100 small and medium enterprises (SMEs), with the examination method possibly being a basic irregular inspection. This study uses a Partial Least Square (PLS) approach. PLS is a condition model for Structural Equation Modeling (SEM) in terms of parts or variations. The results of this study are that access to finance has a positive and significant effect on the growth of SMEs. Financial literacy has a positive and significant effect on the growth of SMEs. Financial literacy moderates the relationship between access to finance and the growth of SMEs. The implication of this research is that this research can be used as a support for strategic decisions regarding the development of SMEs in areas in developing countries.

Abstrak
Penelitian ini dimaksudkan untuk mengetahui bagaimana peran
literasi keuangan dalam memoderasi hubungan akses ke keuangan dan
pertumbuhan. Area eksplorasi dilaksanakan di Denpasar. Jumlah tes yang
diambil adalah 100 usaha kecil menengah (UKM), dengan metode
pemeriksaan kemungkinan merupakan pemeriksaan tidak teratur dasar.
Penelitian ini menggunakan pendekatan Partial Least Square (PLS). PLS
adalah model kondisi untuk Structural Equation Modeling (SEM) dilihat
dari bagian atau variasinya. Hasil penelitian ini adalah akses keuangan
berpengaruh positif dan signifikan terhadap pertumbuhan UKM. Literasi
keuangan berpengaruh positif dan signifikan terhadap pertumbuhan UKM.
Literasi keuangan memoderasi hubungan antara akses keuangan dan
pertumbuhan UKM. Implikasi dari penelitian ini adalah penelitian ini dapat
digunakan sebagai pendukung keputusan-keputusan strategis mengenai
perkembangan UKM di daerah-daerah di negara berkembang.

Fakultas Ekonomi dan Bisnis Universitas Ngurah Rai, Denpasar, Bali - Indonesia ${ }^{2,3}$

Email: ria.sawitri@un.ac.id 


\section{PENDAHULUAN}

Pada perekonomian dunia saat ini, industri kreatif merupakan salah satu sektor industri yang pertumbuhannya paling pesat (UNCTAD, 2011; UNESCO, 2012). Industri-industri ini memberikan kontribusi yang signifikan terhadap penciptaan pendapatan dunia, lapangan kerja dan pendapatan ekspor (UNESCO dan UNDP, 2013). Selain kontribusi ini, bisnis kreatif dan budaya itu unik. Berbeda dengan sektor ekonomi lain di mana individu terutama diatur oleh logika ekonomi, pengusaha di industri kreatif mempraktikkan logika ekonomi dan artistik (Bourdieu, 1990, 2003; Eikhof \& Haunschild, 2007). Logika artistik dimanifestasikan dalam orientasi artistik seorang seniman. Orientasi artistik adalah kecenderungan individu untuk menghasilkan atau melakukan karya asli (Milem, 1998) dengan menekankan aspek estetika dari materi pelajaran (Smelser, 1997), melakukan pendekatan produksi abstrak (Fore, 2007; Harrison, 1995) dan menggunakan artistik sumber daya, dengan tujuan utama mencapai keinginan artis untuk inklusi bebas dan disesuaikan (Ambrose \& Anstey, 2007). Pengusaha artis atau pemilik usaha yang memiliki tingkat orientasi artistik tinggi sangat terlibat dengan aspek artistik dalam karya kreatif, lebih antusias untuk mencoba berinovasi secara artistik, dan berniat untuk mengeksplorasi melampaui batas (Park et al., 2013; Tran, 2010), yang kemudian berpotensi menghasilkan produk kreatif dan budaya yang bernilai tinggi. Karakteristik ini diperlukan agar perusahaan kreatif dapat bersaing dan berhasil di pasar. Namun, sedikit usaha telah dilakukan untuk menguji secara empiris hubungan antara orientasi artistik dan kesuksesan bisnis. Memiliki kemampuan artistik diperlukan tetapi tidak cukup untuk bisnis di industri kreatif dan budaya (Chaston, 2008). Jika bertujuan untuk kelangsungan hidup, pertumbuhan dan keberlanjutan bisnis, pengusaha artis membutuhkan orientasi kewirausahaan. Studi terbaru menunjukkan bahwa orientasi kewirausahaan memfasilitasi wirausahawan untuk mencapai kesuksesan bisnis (Shalender, 2018; Zainol \& Al Mamun, 2018).

Orientasi kewirausahaan didefinisikan sebagai arah pemikiran, kecenderungan, atau minat yang langgeng berkaitan dengan kewirausahaan (Covin \& Lumpkin, 2011). Sebagai fenomena perilaku, orientasi kewirausahaan adalah seperangkat perilaku yang berbeda tetapi terkait yang memiliki kualitas inovasi, proaktif, agresivitas kompetitif, pengambilan risiko dan otonomi (Pearce et al., 2010, Sumerta et al., 2020). Lebih lanjut, Covin \& Slevin (1991) mengemukakan bahwa perilaku kewirausahaan memiliki tiga elemen yang mendasari, yaitu: pengambilan risiko, proaktif dan inovasi. Selain itu, orientasi kewirausahaan berperan dalam konteks organisasi untuk memfasilitasi bundling sumber daya perusahaan untuk mencapai kinerja perusahaan (Wiklund \& Shepherd, 2003, Sumerta, et al., 2020). Dalam industri di mana produk dihargai oleh orisinalitas dan kreativitasnya, entitas bisnis yang dipimpin oleh seniman wirausaha yang menunjukkan perilaku inovatif, proaktif dan berani mengambil risiko (Miller, 1983). Pengusaha seniman biasanya menghadapi situasi dilematis baik dalam memprioritaskan orientasi pasar eksplisit mereka untuk mencapai keuntungan finansial, atau memfokuskan terutama pada keterlibatan mereka dalam proses penciptaan seni (Eikhof dan Haunschild, 2007). Pertukaran antara tujuan artistik dan finansial mengharuskan seniman memiliki kemampuan artistik dan finansial. Meskipun beberapa seniman mungkin mengundang orang lain untuk mengelola keuangannya, pasar budaya saat ini menuntut seniman untuk memiliki pengetahuan dasar keuangan, selain kemampuan artistiknya. Hal ini terkait dengan fakta bahwa sebagian besar pengusaha artis bekerja atas dasar wiraswasta atau bekerja dalam kelompok kecil di mana mereka memainkan peran dominan dalam manajemen dan pengambilan keputusan (Taylor dan Littleton, 2008). Literasi keuangan hanyalah sebuah kemampuan untuk memahami bagaimana uang bekerja di

Pengaruh Akeses Keuangan Terhadap Pertumbuhan UKM Dengan Literasi Keuangan Sebagai Variabel 
dunia (Servon dan Kaestner, 2008). Studi yang ada menegaskan bahwa kinerja bisnis dikaitkan dengan literasi keuangan. Dahmen dan Rodríguez (2014) melaporkan bahwa kesuksesan bisnis kecil dikaitkan dengan literasi keuangan pengusaha mereka. Selain itu, pemahaman tentang masalah keuangan dasar oleh wirausahawan berdampak positif pada kelangsungan usaha baru (Wise, 2013). Literasi pemilik bisnis terhadap tema keuangan juga secara positif meningkatkan akses ke keuangan dan hubungan pertumbuhan perusahaan (Adomako et al., 2016).

Sarjana seperti Abor \& Quartey (2010) menyarankan bahwa Usaha Kecil dan Menengah (UKM) mendorong pembangunan ekonomi, terutama di negara berkembang. Bank Dunia (2015) mengamati bahwa UKM berkontribusi hingga 45\% terhadap total lapangan kerja dan 33\% terhadap pendapatan nasional di negara berkembang. Namun, para sarjana seperti Schiffer \& Weder (2001); Cressy (2002); dan Beck et al., (2008) berpendapat bahwa peran UKM dalam pembangunan ekonomi telah dibatasi oleh kurangnya akses ke layanan keuangan, terutama dari lembaga keuangan formal. Hal ini disebabkan rendahnya tingkat literasi keuangan di kalangan pemilik dan pengelola UKM. Dengan demikian, De Mel, McKenzie \& Woodruff (2012) mengamati bahwa literasi keuangan melalui pelatihan bisnis, menghasilkan perolehan pengetahuan keuangan dan keterampilan bisnis yang diperlukan untuk pertumbuhan UKM di negara berkembang (lihat juga Balarezo \& Nielsen, 2017; Bruhn, Karlan \& Schoar, 2010).

UKM tidak hanya mengembangkan kemampuan yang kuat untuk bersaing secara lokal, tetapi mereka juga menginternasionalkan dan bersaing secara global. Literatur tentang perusahaan internasionalisasi global atau awal yang lahir menyoroti kemampuan UKM untuk mengidentifikasi peluang di pasar internasional sejak awal mereka (Dow, 2017; McDougall, 1989; McDougall \& Oviatt, 2000; Oviatt \& McDougall, 1994). Untuk menerapkan strategi internasional ini, UKM perlu mengembangkan literasi keuangan untuk memahami dan melaksanakan rencana yang efektif untuk mengakses keuangan. Memang, Fatoki (2014) percaya bahwa pemilik UKM yang melek finansial cenderung membuat keputusan keuangan yang lebih baik dengan lebih sedikit kesalahan manajemen daripada rekan mereka yang buta huruf secara finansial. Hal ini didukung oleh Okello, Ntayi, Munene \& Nkote (2016) yang menemukan bahwa literasi keuangan membantu individu untuk membuat keputusan dan pilihan keuangan yang bijak, yang meningkatkan akses dan penggunaan layanan keuangan oleh UKM. Lebih lanjut, MasterCard (2011) juga mengamati bahwa literasi keuangan membantu pemilik UKM untuk mengevaluasi produk keuangan dan, dengan demikian, membuat keputusan yang tepat yang memfasilitasi pengelolaan utang yang tepat di antara pemilik UKM. Tingkat literasi keuangan yang rendah dapat menghalangi UKM untuk menilai dan memahami pilihan pembiayaan yang berbeda secara memadai, dan dari menavigasi prosedur pengajuan pinjaman yang kompleks. Temuan Karlan \& Valdivia (2011) menunjukkan bahwa program pendidikan bisnis untuk perempuan pengusaha mikro di Peru meningkatkan pencatatan UKM. Hal ini sejalan dengan Drexler, Fischer \& Schoar (2011) yang menemukan bahwa pelatihan berbasis aturan ibu jari dalam literasi keuangan menghasilkan peningkatan hasil bisnis di kalangan UKM di Republik Dominika. Selain itu, Bruhn \& Zia (2011) berpendapat bahwa pelatihan bisnis dan keuangan formal meningkatkan praktik bisnis dan investasi di antara perusahaan skala menengah di Bosnia-Herzegovina. Dengan demikian, dapat dikatakan bahwa literasi keuangan, yang memerlukan perolehan pengetahuan dan keterampilan keuangan, membantu pemilik UKM untuk membuat keputusan dan pilihan keuangan yang bijaksana. Studi sebelumnya seperti Abor \& Quartey (2010); Karlan \& Valdivia (2011); Drexler, Fischer \& Schoar (2011); Aghion \& Bolton (1997); Kevane \& Wydick (2001); Schiffer \& Weder (2001); Cressy (2002); Beck et al., (2008), Lois \& Annette (2005) telah meneliti dampak akses keuangan terhadap Pengaruh Akeses Keuangan Terhadap Pertumbuhan UKM Dengan Literasi Keuangan Sebagai Variabel 
pertumbuhan UKM di negara maju dan berkembang. Namun, studi ini mengabaikan peran moderasi literasi keuangan dalam hubungan antara akses keuangan dan pertumbuhan UKM di negara berkembang. Selain itu, Adomako, Danso \& Ofori (2016) juga meneliti pengaruh moderasi literasi keuangan terhadap hubungan antara akses keuangan dan pertumbuhan perusahaan di Ghana. Namun, studi mereka pada dasarnya berfokus pada UKM secara umum dan tidak spesifik perusahaan. Selain itu, studi mereka dilakukan di Ghana dengan pengaturan kelembagaan yang berbeda dibandingkan dengan Uganda. Serupa dengan itu, Otoritas Investasi Uganda (2016) juga berpendapat bahwa 80\% UKM di Uganda gagal untuk bertahan dan berhenti beroperasi dalam tahun pertama dimulainya, sebagian karena pengambilan keputusan dan pilihan investasi yang buruk, yang mungkin tidak terjadi di negara lain. negara di kawasan ini, seperti Ghana. Secara teoritis, Schumpeter (1991) mendefinisikan wirausahawan sebagai seseorang yang membangun bisnis baru untuk menghasilkan produk baru atau membuat produk lama dengan cara baru. Schumpeter berpendapat bahwa wirausahawan adalah inovator, bukan peniru dalam produksi dan, sebagai inovator, secara alami dia adalah monopoli. Karena kemajuan ekonomi berasal dari inovasi, monopoli inovator harus dilindungi dan kewirausahaan harus didorong.

Dengan demikian, pengusaha membutuhkan sumber daya finansial dalam proses ekonomi agar dapat memanfaatkan peluang yang ada di pasar. Namun, ahli teori kewirausahaan seperti Schumpeter mengabaikan faktor-faktor seperti literasi keuangan yang membantu pengusaha inovatif untuk membuat keputusan investasi dalam proses ekonomi. Oleh karena itu, tujuan utama penelitian ini adalah untuk mengeksplorasi dan memahami peran moderasi literasi keuangan dalam hubungan antara akses keuangan dan pertumbuhan UKM. Literasi keuangan membantu manajer untuk membuat keputusan dan pilihan investasi strategis yang memungkinkan perusahaan dapat tumbuh dan berkembang. Studi tersebut mengungkapkan bahwa literasi keuangan secara signifikan memoderasi hubungan antara akses keuangan dan pertumbuhan UKM. Penelitian terdahulu yang menyatakan adanya pengaruh moderasi literasi keuangan terhadap hubungan antara akses kuangan di Ghana (Adomako, Danso \& Ofori, 2016) akan tetapi adanya Gap yang terjadi pada Otoritas Investasi Uganda (2016) juga berpendapat bahwa 80\% UKM di Uganda gagal untuk bertahan dan berhenti beroperasi dalam tahun pertama dimulainya, sebagian karena pengambilan keputusan dan pilihan investasi yang buruk, yang mungkin tidak terjadi di negara lain.

Dengan demikian, studi ini berkontribusi pada literatur kewirausahaan internasional yang ada dengan menunjukkan peran yang kuat dari literasi keuangan dalam mempromosikan akses keuangan dan pertumbuhan di kalangan UKM. Ini membantu manajer UKM untuk memperoleh pengetahuan, keterampilan dan kemampuan untuk menyusun strategi keputusan dan pilihan keuangan mereka. Selain itu, ini mempersiapkan UKM untuk masa keuangan yang sulit melalui strategi yang mengurangi risiko seperti menghindari pinjaman berlebih.

Akses ke keuangan dan manajemen keuangan telah diidentifikasi dalam banyak survei bisnis sebagai faktor terpenting dalam menentukan kelangsungan hidup dan pertumbuhan UKM (IFC, 2010; OECD, 2006). Beck \& Demirguc-Kunt, (2006) berpendapat bahwa akses ke keuangan memungkinkan UKM di negara berkembang untuk melakukan investasi produktif untuk mengembangkan bisnis mereka dan memperoleh teknologi terbaru, sehingga memastikan daya saing mereka, dan mendorong inovasi, ketahanan ekonomi makro, dan PDB pertumbuhan. Kevane \& Wydick (2001) juga menyatakan bahwa pemberian kredit kepada usaha mikro mendorong pertumbuhan ekonomi di sektor informal melalui peningkatan kapitalisasi usaha, penciptaan

Pengaruh Akeses Keuangan Terhadap Pertumbuhan UKM Dengan Literasi Keuangan Sebagai Variabel 
kesempatan kerja, dan pertumbuhan pendapatan jangka panjang. Hal ini didukung oleh Aghion \& Bolton (1997) yang berpendapat bahwa lebih banyak kredit berarti lebih banyak kewirausahaan, lebih banyak pembentukan perusahaan, dan pertumbuhan ekonomi. Para ahli seperti Tiwari, Shahbaz \& Islam (2013) mendalilkan bahwa penyediaan keluarga yang kurang mampu secara finansial dengan pinjaman berbiaya rendah dan peningkatan akses ke berbagai sumber pendanaan, yang digunakan untuk pertumbuhan bisnis dapat mengarah pada pengentasan kemiskinan dan penciptaan lapangan kerja (lihat juga Davidsson, Achtenhagen \& Naldi, 2010). Sebuah studi oleh Bank Dunia (2013) menunjukkan bahwa akses ke keuangan meningkatkan kinerja dan pertumbuhan perusahaan dengan memfasilitasi masuknya pasar, pengurangan risiko, mempromosikan inovasi, dan aktivitas kewirausahaan di negara berkembang. Oleh karena itu, hipotesis yang dapat dibentuk adalah: H1: Akses keuangan berpengaruh signifikan terhadap pertumbuhan UKM.

United Nations (2003) menyatakan bahwa literasi keuangan, yaitu kemampuan menggunakan pengetahuan dan keterampilan untuk mengelola sumber daya keuangan, merupakan bahan kunci keberhasilan keuangan UKM di negara berkembang, terutama sebagai alat untuk memerangi kemiskinan. Karya ilmiah menunjukkan bahwa UKM yang dijalankan oleh pengusaha yang melek keuangan memiliki peluang lebih tinggi untuk menjadi lebih sukses daripada UKM yang dijalankan oleh pengusaha yang buta huruf. Literasi keuangan memungkinkan manajer dan pemilik UKM di negara berkembang untuk membuat keputusan dan pilihan keuangan yang tepat tentang produk keuangan kompleks yang ditawarkan oleh sistem keuangan tanpa merasa terintimidasi. Bukti kuat menunjukkan hubungan yang kuat antara literasi keuangan dan kesuksesan wirausahawan. Peneliti lainnya seperti Lusardi \& Tufano (2009); Moore (2003) mengamati bahwa literasi keuangan membantu manajer UKM di negara berkembang untuk memperoleh pengetahuan, keterampilan, dan kemampuan untuk menyusun strategi keuangan keputusan dan pilihan keuangan mereka. Nunoo \& Andoh (2012) menemukan bahwa literasi keuangan berpengaruh positif terhadap kinerja UKM di Ghana yang cenderung lebih menabung dan memiliki manajemen risiko yang lebih baik dengan membeli kontrak asuransi. Hal ini sejalan dengan penelitian Simeyo et al., (2011) yang mengungkapkan bahwa pelatihan literasi keuangan di kalangan usaha mikro di Kenya memiliki pengaruh positif yang signifikan terhadap kinerja mereka. Dengan demikian, literasi keuangan memfasilitasi ekspansi UKM dan meningkatkan profitabilitas, produktivitas, dan keunggulan kompetitif mereka. Oleh karena itu, di sini kami memperoleh hipotesis bahwa: H2: Literasi keuangan secara signifikan mempengaruhi pertumbuhan UKM.

Kurangnya keterampilan manajemen bisnis dapat memperbesar hambatan keuangan bagi UKM. Tingkat literasi keuangan yang rendah dapat menghalangi tingkat kinerja UKM untuk menilai dan memahami ketentuan pembiayaan yang berbeda secara memadai, dan untuk menavigasi prosedur pengajuan pinjaman yang kompleks. Menurut Bosma \& Harding (2006), banyak UKM di negara berkembang gagal karena kurangnya literasi keuangan dan mereka memiliki ketajaman bisnis yang tidak memadai, sehingga mengurangi aktivitas kewirausahaan. Memang, Spinelli, Timmons \& Adams (2011) mengamati bahwa literasi keuangan diidentifikasi sebagai salah satu kompetensi manajerial penting dalam perusahaan dan pengembangan UKM.

Oseifuah (2010) mengemukakan bahwa wirausahawan, tanpa memandang usia mereka, secara konsisten terlibat dalam kegiatan pengambilan keputusan terkait pengadaan, alokasi, dan pemanfaatan sumber daya. Kegiatan semacam itu selalu memiliki konsekuensi finansial dan karenanya, agar efektif, pengusaha harus melek finansial. Selain itu, para ahli seperti Fidler \& Webster

Pengaruh Akeses Keuangan Terhadap Pertumbuhan UKM Dengan Literasi Keuangan Sebagai Variabel 
(1996) berpendapat bahwa pelatihan keterampilan bisnis dasar sangat penting dalam menyertai pemberian pinjaman mikro untuk meningkatkan kapasitas pengelola UKM dalam menggunakan pinjaman. Selain itu, juga memberikan pengetahuan dalam penggunaan produk dan layanan keuangan yang lebih efektif. Hal ini mengurangi kerentanan mereka terhadap lembaga keuangan yang terlalu bersemangat dan skema penipuan. Hal ini didukung oleh Mutegi \& Phelister (2015) yang mengungkapkan bahwa literasi keuangan memfasilitasi proses pengambilan keputusan seperti pembayaran tagihan tepat waktu, pengelolaan utang yang tepat, yang meningkatkan kelayakan kredit UKM untuk mendukung mata pencaharian, pertumbuhan ekonomi, sistem keuangan yang sehat., dan pengentasan kemiskinan. Siekei (2013) juga menyatakan bahwa keterampilan manajemen kredit yang diperoleh melalui program literasi keuangan membantu pemilik UKM dalam pengelolaan portofolio pinjaman untuk memastikan bahwa kewajiban pinjaman dapat diminimalkan dan biaya bunga dapat diminimalkan. Literasi keuangan membantu pemilik UKM untuk memperoleh pengetahuan dan keterampilan keuangan yang diperlukan untuk perencanaan bisnis, memulai rencana tabungan, dan membuat keputusan investasi strategis (Greenspan, 2002). Dengan demikian, penerapan pengetahuan dan keterampilan keuangan yang tepat membantu pemilik UKM di negara berkembang untuk memenuhi kewajiban keuangan mereka melalui perencanaan, alokasi sumber daya, dan penurunan utilitas. Oleh karena itu, kami memperoleh hipotesis bahwa: H3: Literasi keuangan secara signifikan memoderasi hubungan antara akses keuangan dan pertumbuhan UKM. Dari penjelasan di atas, dapat digambarkan secara skematis seperti pada gambar di bawah ini:

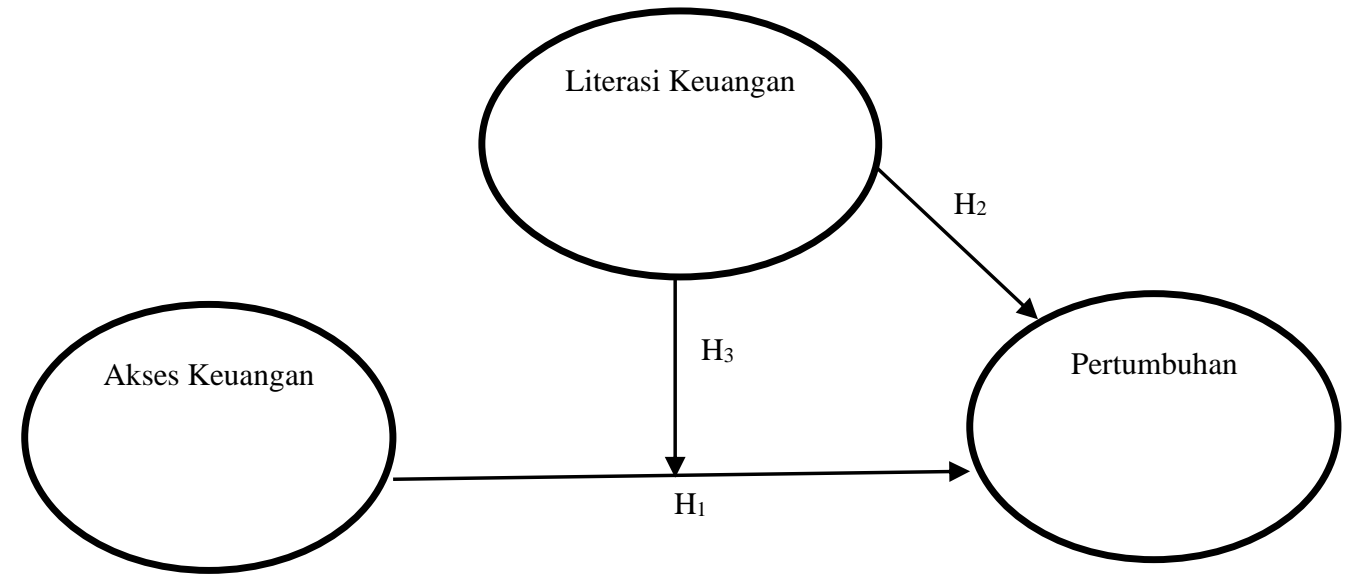

Sumber: Mutegi \& Phelister (2015); Siekei (2013); Okello, et al, (2017)

Gambar 1. Kerangka Konseptual.

\section{METODE PENELITIAN}

Penelitian ini merupakan replikasi dari penelitian Okello, et al, (2017), yang membedakan adalah penelitian ini dilakukan di Kota Denpasar. Kajian tentang peran literasi keuangan dalam memoderasi hubungan akses keuangan dan pertumbuhan dilakukan di Denpasar dengan pertimbangan bahwa Usaha Kecil Menengah (UKM) terbesar ada di Kota Denpasar. Tes yang diambil bergantung pada strategi pemeriksaan kemungkinan adalah pemeriksaan arbitrer dasar, di mana spesialis memberikan kesempatan yang setara kepada setiap individu dari populasi untuk dipilih sebagai tes yang secara sewenang-wenang memberikan sedikit rasa hormat pada strata dalam populasi itu sendiri

Pengaruh Akeses Keuangan Terhadap Pertumbuhan UKM Dengan Literasi Keuangan Sebagai Variabel 
dengan contoh absolut dari 100 responden. Skala estimasi yang digunakan dalam penelitian ini adalah skala likert, yang merupakan skala yang biasanya digunakan untuk meminta responden memberi cap derajat dari pengesahan atau konflik dengan perkembangan objek perbaikan. Skala Likert yang digunakan adalah 1 untuk sangat berbeda dengan 5 sangat setuju.

Penyelidikan informasi dalam penelitian ini menggunakan pendekatan Partial Least Square (PLS). PLS adalah model kondisi untuk Structural Equation Modeling (SEM) dilihat dari segmen atau variasinya. Untuk melengkapi hipotesis dan menghasilkan model yang membumi, pengujian ini menggunakan Structural Equation Modeling (SEM) dengan prosedur berbasis vacillation atau sectionbased dengan Partial Least Square (PLS). PLS digunakan dalam penelitian ini agar model penelitian yang dirumuskan dapat menghasilkan hasil yang sesuai.

\section{HASIL DAN PEMBAHASAN}

Penelitian ini menggunakan teknik analisis data SEM dengan program Smart PLS. Berdasarkan hasil pengolahan data menggunakan PLS, selanjutnya mengikuti model persamaan struktural. Dalam evaluasi ini terdapat dua evaluasi evaluasi, yaitu: 1) evaluasi model pengukuran (outer model) untuk melihat validitas dan reliabilitas indikator pengukuran variabel laten, dan 2) evaluasi model struktural (inner model) untuk melihat akurasi model. Sebelum dilakukan evaluasi model dapat ditegaskan kembali bahwa instrumen penelitian (angket) sebagai alat pengumpul data adalah instrumen yang valid dan reliabel.

Convergent Validity bertujuan untuk mengukur validitas indikator sebagai konstruk pengukuran yang dapat dilihat pada outer loading (keluaran Smart PLS). Indikator dianggap valid jika memiliki nilai outer loading di atas 0.5 dan atau nilai t-statistik di atas 1.96. Selain itu, nilai outer loading dapat menentukan kontribusi masing-masing indikator terhadap variabel latennya. Pembebanan luar suatu indikator dengan nilai tertinggi menunjukkan bahwa indikator tersebut merupakan ukuran terkuat atau dengan kata lain paling penting dalam variabel latennya.

Dengan melihat informasi pada Tabel 1 terlihat bahwa kesembilan indikator yang mengukur akses keuangan $(\mathrm{X})$ memiliki nilai outer loading lebih besar dari 0,5 dan t-statistic diatas 1,96. Artinya semua indikator merupakan indikator yang valid sebagai tolak ukur variabel akses keuangan (X). Pada evaluasi variabel moderasi literasi keuangan (M), terlihat bahwa kesepuluh indikator tersebut memiliki nilai outer loading di atas 0,50 dan t-statistik jauh di atas 1,96. Hasil tersebut menunjukkan bahwa semua indikator merupakan indikator yang valid untuk mengukur variabel literasi keuangan (M). Dengan melihat hasil evaluasi dapat diketahui bahwa keenam indikator yang mengukur variabel Growth (Y) memiliki nilai outer loading lebih besar dari 0,5 dan t-statistic diatas 1,96. Artinya semua indikator merupakan indikator yang valid sebagai tolak ukur variabel Pertumbuhan (Y).

Adapun hasil pengujian outer model dapat diketahui bahwa outer loading masing-masing indikator pada suatu variable. 
Tabel 1.

Outer Model

\begin{tabular}{|c|c|c|c|}
\hline Variabel & Indikator & Outer Loading & t-statistic \\
\hline Akses Keuangan (X) & $\mathrm{X} 1.1$ & 0.686 & 9.482 \\
\hline & $\begin{array}{c}\text { X1.2 } \\
\text { X1.3 } \\
\text { X1.4 } \\
\text { X1.5 } \\
\text { X1.6 } \\
\text { X1.7 } \\
\text { X1.8 } \\
\text { X1.9 } \\
\text { X1.10 }\end{array}$ & $\begin{array}{l}0.737 \\
0.614 \\
0.566 \\
0.611 \\
0.587 \\
0.754 \\
0.578 \\
0.755 \\
0.618\end{array}$ & $\begin{array}{c}12.035 \\
6.527 \\
6.019 \\
8.261 \\
5.977 \\
14.658 \\
5.399 \\
18.675 \\
8.576\end{array}$ \\
\hline Literasi Keuangan & M1.1. & 0.541 & 7.225 \\
\hline (M) & $\begin{array}{l}\text { M1.2 } \\
\text { M1.3 } \\
\text { M1.4 } \\
\text { M1.5 } \\
\text { M1.6 } \\
\text { M1.7 } \\
\text { M1.8 } \\
\text { M1.9 }\end{array}$ & $\begin{array}{l}0.578 \\
0.668 \\
0.601 \\
0.609 \\
0.634 \\
0.550 \\
0.575 \\
0.509\end{array}$ & $\begin{array}{l}6.437 \\
9.390 \\
6.197 \\
7.079 \\
7.636 \\
5.981 \\
4.795 \\
4.674\end{array}$ \\
\hline Pertumbuhan & Y1.1 & 0.714 & 11.987 \\
\hline$(\mathbf{Y})$ & $\begin{array}{l}\mathrm{Y} 1.2 \\
\mathrm{Y} 1.3 \\
\mathrm{Y} 1.4 \\
\mathrm{Y} 1.5 \\
\mathrm{Y} 1.6 \\
\end{array}$ & $\begin{array}{l}0.758 \\
0.662 \\
0.759 \\
0.738 \\
0.712 \\
\end{array}$ & $\begin{array}{c}12.646 \\
8.925 \\
12.522 \\
12.418 \\
13.584 \\
\end{array}$ \\
\hline
\end{tabular}

Sumber: Data diolah, 2020

Reliabilitas Komposit, bertujuan untuk mengevaluasi nilai reliabilitas antara blok indikator dari konstruk yang membentuknya. Hasil reliabilitas komposit dikatakan baik jika memiliki nilai di atas 0,70 . Untuk mengetahui nilai reliabilitas komposit pada model pengukuran dapat disajikan pada Tabel 2:

Tabel 2.

Uji Reliabilitas

\begin{tabular}{lcc}
\hline & Variabel & Composite Reliability \\
\hline Akses Keuangan (X) & & 0.881 \\
Literasi Keuangan (M) & 0.824 \\
Petumbuhan (Y) & 0.869 \\
\hline
\end{tabular}

Sumber : Data dilah, 2021

Tabel 2 menunjukkan nilai composite reliability dari ketiga variabel laten berada diatas 0,70, sehingga dapat dikatakan bahwa blok indikator reliabel mengukur variabel tersebut.

Pengujian hipotesis dilakukan dengan uji-t pada masing-masing jalur pengaruh langsung secara parsial dan melalui variabel moderasi. Bagian berikut menjelaskan hasil uji pengaruh langsung parsial dan uji variabel moderasi.

Pengaruh Akeses Keuangan Terhadap Pertumbuhan UKM Dengan Literasi Keuangan Sebagai Variabel 
Tabel 3.

Pengaruh Langsung dan Moderasi

\begin{tabular}{ccccc}
\hline No & Hubungan Variabel & Path Coefficient & t-statistic & Hasil \\
\hline $\mathbf{1}$ & $\mathrm{X} \rightarrow \mathrm{Y}$ & 0.358 & 3.734 & Signifikan \\
$\mathbf{2}$ & $\mathrm{M} \rightarrow \mathrm{Y}$ & 0.420 & 4.598 & Signifikan \\
$\mathbf{3}$ & $\mathrm{X} \rightarrow \mathrm{M} \rightarrow \mathrm{Y}$ & 0.564 & 7.458 & Signifikan \\
\hline
\end{tabular}

Sumber : Data diolah, 2021

Akses Keuangan (X) berpengaruh positif dan signifikan terhadap Pertumbuhan (Y). Hasil ini ditunjukkan oleh koefisien jalur positif sebesar 0,358 dengan t-statistik = 3,734 (t-statistik>1,96). Hasil tersebut menunjukkan bahwa hipotesis akses keuangan berpengaruh positif dan signifikan terhadap pertumbuhan UMKM, terbukti secara empiris. Berdasarkan hasil tersebut dapat dinyatakan bahwa semakin kuat akses keuangan maka pertumbuhan UKM akan semakin meningkat. Hasil pada tabel 3 di atas menunjukkan bahwa terdapat hubungan yang signifikan antara akses keuangan dengan pertumbuhan UKM. Hal ini mendukung hipotesis kami (H1) dari studi tersebut, yang menyatakan bahwa akses keuangan secara signifikan mempengaruhi pertumbuhan UKM. OECD (2006) \& IFC (2010) berpendapat bahwa akses ke keuangan diperlukan untuk penciptaan lingkungan ekonomi yang memungkinkan perusahaan untuk tumbuh dan berkembang. Peningkatan akses keuangan bagi UKM dapat meningkatkan kondisi ekonomi di negara berkembang dengan mendorong inovasi, ketahanan ekonomi makro, dan pertumbuhan PDB. Menurut Kevane \& Wydick (2001), pemberian kredit kepada usaha mikro mendorong pertumbuhan ekonomi di sektor informal melalui peningkatan kapitalisasi usaha, penciptaan lapangan kerja, dan pertumbuhan pendapatan jangka panjang. Hal ini didukung oleh Aghion \& Bolton (1997) yang mengamati bahwa lebih banyak kredit berarti lebih banyak kewirausahaan, pembentukan yang lebih kuat, dan pertumbuhan ekonomi.

Literasi Keuangan (M) berpengaruh positif dan signifikan terhadap Pertumbuhan (Y). Hasil ini ditunjukkan oleh koefisien jalur positif sebesar 0,420 dengan t-statistic $=4,598$ (t-statistic > 1,96). Hasil tersebut menunjukkan bahwa hipotesis literasi keuangan berpengaruh positif dan signifikan terhadap pertumbuhan UKM, terbukti secara empiris. Berdasarkan hasil tersebut dapat dinyatakan bahwa semakin kuat literasi keuangan maka pertumbuhan UKM akan semakin meningkat. Selain itu, hasil penelitian menunjukkan bahwa literasi keuangan dan pertumbuhan UKM berpengaruh positif dan signifikan, oleh karena itu mendukung hipotesis (H2) penelitian kami, yang menyatakan bahwa literasi keuangan berpengaruh signifikan terhadap pertumbuhan UKM. Literasi keuangan, yaitu kemampuan untuk menggunakan pengetahuan dan keterampilan untuk mengelola sumber daya keuangan secara efektif untuk kesejahteraan keuangan seumur hidup, merupakan unsur utama keberhasilan keuangan UKM, terutama sebagai alat untuk memerangi kemiskinan di negara berkembang. Memang, penelitian ilmiah yang ada menunjukkan bahwa UKM yang dijalankan oleh wirausahawan yang melek keuangan memiliki peluang lebih tinggi untuk menjadi lebih sukses daripada UKM yang dijalankan oleh mitra yang buta huruf. Literasi keuangan, yaitu kemampuan untuk menggunakan pengetahuan dan keterampilan keuangan untuk mengelola sumber daya keuangan secara efektif, merupakan unsur kunci keberhasilan keuangan UKM, terutama sebagai alat untuk memerangi kemiskinan (United Nations, 2003). UKM yang dijalankan oleh pengusaha yang melek keuangan memiliki peluang lebih tinggi untuk menjadi lebih sukses daripada yang dijalankan oleh pengusaha yang buta huruf. Literasi keuangan memungkinkan manajer dan pemilik UKM di negara berkembang untuk membuat keputusan dan pilihan keuangan tentang produk keuangan kompleks

Pengaruh Akeses Keuangan Terhadap Pertumbuhan UKM Dengan Literasi Keuangan Sebagai Variabel 
yang ditawarkan oleh sistem keuangan tanpa merasa terintimidasi. Bukti yang meyakinkan menunjukkan hubungan yang kuat antara literasi keuangan dan kesuksesan wirausahawan di negara berkembang. Sarjana seperti Lusardi \& Tufano (2009); Moore (2003) berpendapat bahwa literasi keuangan membantu manajer UKM untuk memperoleh pengetahuan, keterampilan, dan kemampuan untuk menyusun strategi keuangan untuk membuat keputusan dan pilihan keuangan. Dengan demikian, literasi keuangan memfasilitasi ekspansi UKM dan meningkatkan profitabilitas, produktivitas, dan keunggulan kompetitif mereka.

Literasi keuangan (M) memoderasi hubungan Akses ke keuangan (X) secara positif dan signifikan terhadap Pertumbuhan (Y). Hasil ini ditunjukkan oleh koefisien jalur positif sebesar 0,564 dengan t-statistic $=7,458$ (t-statistic $>1,96$ ). Hasil ini berarti bahwa akses keuangan akan mengarah pada literasi keuangan. Hal tersebut tentunya akan meningkatkan pertumbuhan usaha kecil dan menengah (UKM). Lebih dari itu, hasil regresi hierarkis menunjukkan bahwa literasi keuangan secara signifikan memoderasi hubungan antara akses keuangan dan pertumbuhan UKM. Pengaruh interaksi antara literasi keuangan dan akses keuangan adalah positif dan signifikan. Memang, Aiken \& West (1991) menetapkan bahwa dua variabel berinteraksi jika kombinasi tertentu dari variabel-variabel ini mengarah pada hasil yang tidak diantisipasi atas dasar pengaruh utama dari variabel-variabel tersebut. Oleh karena itu, karena pengaruh interaksi signifikan dan positif dalam model terakhir (model 3), kita dapat menyimpulkan bahwa hipotesis penelitian kami (H3) didukung. Memang, Spinelli et al., (2011) berpendapat bahwa literasi keuangan diidentifikasi sebagai salah satu kompetensi manajerial yang kritis dalam perusahaan UKM dan pembangunan di negara berkembang. Selain itu, Oseifuah (2010) mengemukakan bahwa wirausahawan, terlepas dari usianya, secara konsisten terlibat dalam kegiatan pengambilan keputusan mengenai pengadaan, alokasi, dan pemanfaatan sumber daya. Kegiatan semacam itu selalu memiliki konsekuensi finansial, oleh karena itu, agar efektif, pengusaha di negara berkembang harus melek finansial. Selain itu, Fidler \& Webster (1996) juga mengemukakan bahwa pelatihan keterampilan bisnis dasar harus menyertai pemberian pinjaman mikro untuk meningkatkan kapasitas pengelola UKM dalam menggunakan dana. Selain itu, ini juga memberikan kontrol yang lebih besar dan penggunaan produk dan layanan keuangan yang lebih efektif, dan mengurangi kerentanan terhadap skema yang terlalu bersemangat dan curang. Demikian pula, Greenspan (2002) berpendapat bahwa literasi keuangan membantu pemilik UKM untuk memperoleh pengetahuan keuangan yang diperlukan untuk membuat perencanaan bisnis, memulai rencana tabungan, dan membuat keputusan investasi strategis.

\section{SIMPULAN DAN SARAN}

Hasil penelitian menunjukkan bahwa terdapat hubungan yang signifikan antara akses keuangan dan pertumbuhan UKM di negara berkembang. Selain itu, hasil regresi juga mengungkapkan bahwa literasi keuangan berpengaruh signifikan terhadap akses keuangan oleh UKM di negara berkembang. Hasil penelitian menunjukkan bahwa ada pengaruh signifikan literasi keuangan terhadap pertumbuhan UKM di negara berkembang. Terakhir, hasil regresi hierarkis menunjukkan bahwa literasi keuangan secara signifikan memoderasi hubungan antara akses keuangan dan pertumbuhan UKM di negara berkembang.

Studi ini mengandalkan data yang dikumpulkan dari satu wilayah yaitu Kota Denpasar. Wilayah lain yang terletak di kawasan lain mungkin menghadapi tantangan serupa tetapi dalam lingkungan kelembagaan yang berbeda. Lebih lanjut, temuan dari studi ini didasarkan pada data

Pengaruh Akeses Keuangan Terhadap Pertumbuhan UKM Dengan Literasi Keuangan Sebagai Variabel 
kuantitatif yang dikumpulkan melalui penggunaan kuesioner semi-terstruktur, dan ada kemungkinan untuk lebih memahami alasan mengapa dan bagaimana UKM mengakses dan menggunakan keuangan. Selain itu, penelitian ini murni cross-sectional sehingga mengabaikan karakteristik UMKM yang dapat diteliti menggunakan desain studi longitudinal. Oleh karena itu, studi di masa depan dapat mengadopsi penggunaan studi longitudinal untuk menyelidiki perilaku UKM di wilayah lain, yang dapat membatasi akses mereka ke keuangan. Implikasi dari penelitian ini adalah penelitian ini dapat menambah kajian teori terkait literasi keuangan dan dapat menambah sumber acuan dalam membuat keputusan-keputusan strategis terkait perkembangan UKM di daerah-daerah negara berkembang salah satunya Kota Denpasar.

\section{REFERENSI}

Adomako, S., Danso, A. and Ofori Damoah, J. (2016), "The moderating influence of financial literacy on the relationship between access to finance and firm growth in Ghana", Venture Capital, 18(1), 43-61.

Aghion, P. and Bolton, P. (1997), "A Theory Of Trickle-Down Growth and Development. Review of Economic Studies. 64(2), 151-172.

Aiken, L.S. and West, S.G. (1991), Testing and Interpreting Interactions. Sage, Newbury Park, CA

Ambrose, D.M. and Anstey, J.R. (2007), "Better survey design is: easy, difficult or don't Know-Stuck for an answer? Use this seven-element model to ensure that your customer questionnaires are complete and achieve the intended objective", ABA Bank Marketing.

Balarezo, J. and Nielsen, B.B. (2017), "Scenario planning as organizational intervention: An integrative framework and future research directions", Review of International Business and Strategy, 27(1) .2-52

Bourdieu, P. (1990), The Logic of Practice, Cambridge Polity Press, Cambridge.

Beck, T., and Demirguc-Kunt, A. (2006), "Small and medium-size enterprises: Access to finance as a growth constraint", Journal of Banking \& Finance. 30(11), 2931-2943.

Bosma, N. and Harding, R. (2006), Global entrepreneurship monitor: GEM 2006 summary results: Babson College London Business School.

Bruhn, M., Karlan, D. and Schoar, A. (2010), What Capital is Missing in Developing Countries? Mimeo.

Bruhn, M. and Zia, B. (2011). Stimulating managerial capital in emerging markets: the impact of business and financial literacy for young entrepreneurs. World Bank working paper, 5642

Chaston, I. (2008), "Small creative industry firms: a development dilemma?", Management Decision, 46(6), 819-831.

Covin, J.G. and Lumpkin, G.T. (2011), "Entrepreneurial orientation theory and research: reflections on a needed construct", Entrepreneurship Theory and Practice, 35(5) 855-872.

Covin, J.G. and Slevin, D.P. (1991), "A conceptual model of entrepreneurship as firm behavior", Entrepreneurship Theory and Practice, 16(1) 7-25.

Dahmen, P. and Rodríguez, E. (2014), "Financial literacy and the success of small businesses: an observation from a small business development center", Numeracy, 7(1), 3-19.

Davidsson, P., Leona Achtenhagen, L. and Naldi, L. (2010), "Small Firm Growth", Foundations and Trends in Entrepreneurship: 6(2) 69-166.

Dow, D. (2017). "Born global firms and accidental internationalists: Has Hennart (2014) opened a can of worms", Review of International Business and Strategy, 27(3) 286-307.

Drexler, A., Fischer, G. and Schoar, A. (2014), "Keeping it simple: Financial literacy and rules of thumb". American Economic Journal: Applied Economics, 6(2), 1-31.

Eikhof, D.R. and Haunschild, A. (2007), "For art's sake! Artistic and economic logics in creative production", Journal of Organizational Behavior, 28(5) 523-538.

Fatoki, O. (2014), "The Financial Literacy of Micro Entrepreneurs in South Africa", Journal of Social Science, 40(2) $151-158$.

Fore, S. (2007), "Romancing the rotoscope: self-reflexivity and the reality effect in the animations of Jeff Scher", Animation, 2(2), 111-127.

Greenspan, A. (2002), Financial Literacy: A Tool for Economic Progress. The Futurist, 36(4), $37-41$.

Harrison, H.A. (1995), “Stuart Davis's' world of tomorrow”, American Art, 9(3), 96-100.

Pengaruh Akeses Keuangan Terhadap Pertumbuhan UKM Dengan Literasi Keuangan Sebagai Variabel

Moderasi

Made Ayu Desy Geriadi, Luh Erynayati dan Ni Putu Yuliana Ria Sawitri 
IFC, (2010), Scaling-up SME access to financial services in the developing world. Financial inclusion experts group |SME finance sub-group: International Finance Corporation, World Bank Group.

Kevane, M., Wydick, B. (2001). "Microenterprise Lending to Female Entrepreneurs: Sacrificing Economic growth for Poverty Alleviation?", World Development, 29(7) 1225-1236.

Lusardi, A., \& Tufano, P. (2009). Debt literacy, financial experiences, and over indebtedness. Cambridge Mass

MasterCard (2011). Taking Stock: Financial Education Initiatives for the Poor.

Miller, D. (1983), "The correlates of entrepreneurship in three types of firms", Management Science, 29(7), 770791.

Mutegi, K. and Phelister, N. (2015). Financial literacy and its impact on loan repayment by small and medium entrepreneurs. International journal of economics, commerce and management United Kingdom.

Okello, G.C.B., Ntayi, J.M., Munene, J.C. and Nkote, N.I. (2016), "Financial Inclusion in Rural Uganda: Testing Interaction Effect of Financial Literacy and Networks", Journal of African Business, 17(1), 106-128.

Organization for Economic Cooperation and Development, (2006), The SME Financing Gap, Volume I, Theory And Evidence, OECD

Oseifuah, K. E. (2010). Financial literacy and youth entrepreneurship in South Africa. African Journal of Economic and Management Studies, 1(2), 164-182.

Schumpeter, J.A. (1991), Essays on Entrepreneurs, Innovations, Business Cycles and The Evaluation of Capitalism. New Brunswick and London, Transactions Publications.

Servon, L.J. and Kaestner, R. (2008), "Consumer financial literacy and the impact of online banking on the financial behavior of lower-income bank customers", Journal of Consumer Affairs, 42(2), 271-305.

Shalender, K. (2018), "Entrepreneurial orientation for sustainable mobility through electric vehicles: Insights from international case studies", Journal of Enterprising Communities: People and Places in the Global Economy, 12(1), 67-82.

Simeyo, O., Lumumba, M., Nyabwanga, R. N., Ojera P. and Odondo, A. J. (2011). Effect of Provision of Microfinance on performance of micro enterprises: A study of Youth micro-enterprises under Kenya Rural Enterprise Program(K-REP), Kisii County, African Journal of Business Management Vol. 5(20), 8290-8300.

Sumerta, IK, Redianingsih, NK, Pranawa, IMB, Indahyani, DNT. (2020) Pengaruh Tingkat Penggunaan Media Sosial Dan Motivasi Terhadap Minat Berwirausaha Pada Mahasiswa Program Studi Manajeman Perguruan Tinggi Di Kota Denpasar. E-Jurnal Ekonomi dan Bisnis Universitas Udayana, 9(7), 627-652.

Taylor, S. and Littleton, K. (2008), "Art work or money: conflicts in the construction of a creative identity", Sociological Review, Vol. 56 No. 2, pp. 275-292.

UNCTAD (2011), Strengthening the Creative Industries for Development, UNCTAD, Geneva

UNESCO (2012), UN System Task Team on the Post-2015 UN Development Agenda: Culture: a Driver and an Enabler of Sustainable Development, UNESCO, Paris.

United Nations (2003), World Population Prospects: The 2002 Revision Population Database, Population Division, United Nations, New York,

World Bank, (2015), Small and Medium Enterprises (SMEs) Finance: The World Bank Key Messages Bulletin: The World Bank DC, Washington

Zainol, N.R. and Al Mamun, A. (2018), "Entrepreneurial competency, competitive advantage and performance of informal women micro-entrepreneurs in Kelantan, Malaysia", Journal of Enterprising Communities: People and Places in the Global Economy, Vol. 12 No. 3, pp. 299-321. 